\title{
Oceanobacillus locisalsi sp. nov., isolated from a marine solar saltern
}

\author{
Soo-Young Lee, ${ }^{1}$ Tae-Kwang Oh, ${ }^{1}$ Wonyong $\mathrm{Kim}^{2}$ and Jung-Hoon Yoon ${ }^{1}$ \\ ${ }^{1}$ Korea Research Institute of Bioscience and Biotechnology (KRIBB), PO Box 115, Yusong, Taejon, \\ Republic of Korea \\ ${ }^{2}$ Department of Microbiology, College of Medicine, Chungang University, 221 Heukseok-dong, \\ Seoul, Republic of Korea
}

Correspondence

Jung-Hoon Yoon

jhyoon@kribb.re.kr
The genus Oceanobacillus was first proposed by $\mathrm{Lu}$ et al. (2001) with the description of a single species, Oceanobacillus iheyensis. Subsequently, four Oceanobacillus species with validly published names, Oceanobacillus oncorhynchi (Yumoto et al., 2005), Oceanobacillus chironomi (Raats \& Halpern, 2007), Oceanobacillus profundus (Kim et al., 2007) and Oceanobacillus caeni (Nam et al., 2008), have been reported; a further species, Oceanobacillus picturae (Lee et al., 2006), was described by the reclassification of Virgibacillus picturae (Heyrman et al., 2003). In this study, the taxonomic characterization of an Oceanobacillus-like bacterium, strain $\mathrm{CHL}-21^{\mathrm{T}}$, which was isolated from a marine solar saltern, is reported.

Sediment samples were collected from a marine solar saltern $\left(35^{\circ} 41^{\prime} 59^{\prime \prime} \mathrm{N} 126^{\circ} 34^{\prime} 33^{\prime \prime} \mathrm{E}\right)$ of the Yellow Sea, Korea, and used for the isolation of bacterial strains. Strain CHL $-21^{\mathrm{T}}$ was isolated by the dilution plating technique at $25{ }^{\circ} \mathrm{C}$ on a modified S-G medium (Sehgal \& Gibbons,

The GenBank/EMBL/DDBJ accession number for the 16S rRNA gene sequence of strain $\mathrm{CHL}-21^{\top}$ is EU817570.
1960) containing ( ${ }^{-1}$ distilled water): $100 \mathrm{~g} \mathrm{NaCl} ; 20 \mathrm{~g}$ $\mathrm{MgSO}_{4} \cdot 7 \mathrm{H}_{2} \mathrm{O} ; 2 \mathrm{~g} \mathrm{KCl} ; 3 \mathrm{~g}$ trisodium citrate; $10 \mathrm{~g}$ yeast extract; and $7.5 \mathrm{~g}$ Casamino acids ( $\mathrm{pH}$ 7.2). The type strains of the two subspecies of Oceanobacillus oncorhynchi and of two other species of the genus Oceanobacillus were used as reference strains for DNA-DNA hybridization and/ or phenotypic characterization. Oceanobacillus oncorhynchi subsp. oncorhynchi JCM $12661^{\mathrm{T}}$ was obtained from the Japan Collection of Microorganisms (JCM), Saitama, Japan. Oceanobacillus oncorhynchi subsp. incaldanensis DSM $16557^{\mathrm{T}}$, Oceanobacillus chironomi DSM $18262^{\mathrm{T}}$ and Oceanobacillus iheyensis DSM $14371^{\mathrm{T}}$ were obtained from the Deutsche Sammlung von Mikroorganismen und Zellkulturen (DSMZ), Braunschweig, Germany. To investigate morphological, physiological and biochemical characteristics, strain CHL- $21^{\mathrm{T}}$ was routinely cultivated at $30{ }^{\circ} \mathrm{C}$ on another modified S-G medium (MSG), which contained $\left(1^{-1}\right.$ distilled water): $50 \mathrm{~g} \mathrm{NaCl} ; 20 \mathrm{~g}$ $\mathrm{MgSO}_{4} .7 \mathrm{H}_{2} \mathrm{O} ; 2 \mathrm{~g} \mathrm{KCl} ; 3 \mathrm{~g}$ trisodium citrate; $10 \mathrm{~g}$ yeast extract; and 7.5 g Casamino acids ( $\mathrm{pH}$ 7.2). Cell morphology was examined by light microscopy (Nikon E600) and transmission electron microscopy. Flagellation was 
determined by using a Philips CM-20 transmission electron microscope with cells from exponentially growing cultures. For this purpose, cells were negatively stained with $1 \%$ $(\mathrm{w} / \mathrm{v})$ phosphotungstic acid and grids were examined after being air-dried. The Gram reaction was performed by using the bioMérieux Gram stain kit according to the manufacturer's instructions. Growth under anaerobic conditions was determined after incubation in a Forma anaerobic chamber on MSG agar [i.e. MSG medium containing $1.5 \%(\mathrm{w} / \mathrm{v})$ agar] and on MSG agar supplemented with $0.1 \%(\mathrm{w} / \mathrm{v})$ potassium nitrate, both of which had been prepared anaerobically under a nitrogen atmosphere. Growth at various temperatures $\left(4-50{ }^{\circ} \mathrm{C}\right)$ was measured on MSG agar. The $\mathrm{pH}$ range for growth was determined in MSG broth adjusted to various $\mathrm{pH}$ (4.5-9.5, at intervals of 0.5 ) by the addition of $\mathrm{HCl}$ or $\mathrm{Na}_{2} \mathrm{CO}_{3}$. Growth at various $\mathrm{NaCl}$ concentrations $[0-30 \%(\mathrm{w} / \mathrm{v})$, in increments of $1.0 \%$ ] was investigated by using liquid media prepared according to the formula of the MSG medium except that $\mathrm{NaCl}$ was excluded. Growth in the absence of $\mathrm{NaCl}$ was also investigated using trypticase soy broth, in the presence and absence of $0.45 \%(\mathrm{w} / \mathrm{v}) \mathrm{MgCl}_{2} \cdot 6 \mathrm{H}_{2} \mathrm{O}$, prepared according to the formula of the Difco medium except that $\mathrm{NaCl}$ was excluded. Catalase and oxidase activities were determined as described by Cowan \& Steel (1965). Nitrate reduction and hydrolysis of aesculin, gelatin, urea and Tweens 20, 40, 60 and 80 were tested as described by Lányí (1987) by using artificial seawater (Bruns et al., 2001) for preparation of media. Hydrolysis of casein, hypoxanthine, starch and xanthine was tested on MSG agar using the substrate concentrations described by Cowan \& Steel (1965). Acid production from carbohydrates was determined according to the method of Leifson (1963). Susceptibility to various antibiotics was investigated on MSG plates by using antibiotic discs of the following: polymyxin B (100 U), streptomycin $(50 \mu \mathrm{g})$, penicillin $\mathrm{G}(20 \mathrm{U})$, ampicillin $(10 \mu \mathrm{g})$, cephalothin $(30 \mu \mathrm{g})$, gentamicin $(30 \mu \mathrm{g})$, novobiocin $(5 \mu \mathrm{g})$, chloramphenicol $(100 \mu \mathrm{g})$, kanamycin $(30 \mu \mathrm{g})$, lincomycin $(15 \mu \mathrm{g})$, neomycin $(30 \mu \mathrm{g})$, oleandomycin $(15 \mu \mathrm{g})$, carbenicillin $(100 \mu \mathrm{g})$, tetracycline $(30 \mu \mathrm{g})$, rifampicin $(5 \mu \mathrm{g})$ and erythromycin $(22.5 \mu \mathrm{g})$. Enzyme activities were determined by using the API ZYM system (bioMérieux).

Cell biomass for DNA extraction and for analysis of cellwall and isoprenoid quinones was obtained from cultures grown in MSG broth at $30{ }^{\circ} \mathrm{C}$. Chromosomal DNA was isolated and purified as described by Yoon et al. (1996) with the exception that RNase T1 was used in combination with RNase A to minimize contamination with RNA. The $16 \mathrm{~S}$ rRNA gene was amplified by PCR using two universal primers as described previously (Yoon et al., 1998). Sequencing of the amplified 16S rRNA gene and phylogenetic analysis were performed according to the method described by Yoon et al. (2003). The isomer type of the diamino acid in the cell-wall peptidoglycan was analysed using TLC according to the method described by Komagata \& Suzuki (1987). Isoprenoid quinones were extracted according to the method of Komagata \& Suzuki (1987) and analysed using reversed-phase HPLC and a YMC ODS-A $(250 \times 4.6 \mathrm{~mm})$ column. For cellular fatty acid analysis, cell mass of strain CHL- $21^{\mathrm{T}}$, Oceanobacillus chironomi DSM $18262^{\mathrm{T}}$, Oceanobacillus iheyensis DSM $14371^{\mathrm{T}}$, Oceanobacillus oncorhynchi subsp. incaldanensis DSM $16557^{\mathrm{T}}$ and Oceanobacillus oncorhynchi subsp. oncorhynchi JCM $12661^{\mathrm{T}}$ was harvested after incubation for 3 days at $30{ }^{\circ} \mathrm{C}$ on marine agar 2216 (Difco). Fatty acids were extracted and fatty acid methyl esters were prepared by the standard protocol of the MIDI/Hewlett Packard Microbial Identification System (Sasser, 1990). The DNA G + C content was determined according to the procedure of Tamaoka \& Komagata (1984) with the modification that DNA was hydrolysed using nuclease P1 (Sigma) and the resultant nucleotides were analysed by reversed-phase HPLC. DNA-DNA hybridization was performed fluorometrically by the method of Ezaki et al. (1989) using photobiotin-labelled DNA probes and microdilution wells. Hybridization was performed with five replications for each sample. The highest and lowest values obtained in each sample were excluded and the mean of the remaining three values was quoted as the DNA-DNA reassociation value.

Morphological, cultural, physiological and biochemical characteristics of strain CHL- $21^{\mathrm{T}}$ are given in the species description (see below) or are shown in Table 1. The almost-complete 16S rRNA gene sequence of strain CHL$21^{\mathrm{T}}$ determined in this study comprised $1520 \mathrm{nt}$. A comparative 16S rRNA gene sequence analysis and estimation of phylogenetic relationships showed that strain CHL- $21^{\mathrm{T}}$ was closely related to members of the genera Oceanobacillus, Ornithinibacillus and Paucisalibacillus (Fig. 1). It exhibited $16 \mathrm{~S}$ rRNA gene sequence similarity values of $97.1-97.2 \%$ to the type strains of the two subspecies of Oceanobacillus oncorhynchi, 93.1-94.7\% to the type strains of the other species of the genus Oceanobacillus, and 92.0$93.3 \%$ to the type strains of two species of the genus Ornithinibacillus and Paucisalibacillus globulus. Mean DNA-DNA reassociation values between strain CHL- $21^{\mathrm{T}}$ and the type strains of the subspecies of Oceanobacillus oncorhynchi were 19-21\% (19\% for O. oncorhynchi subsp. oncorhynchi JCM $12661^{\mathrm{T}} ; 21 \%$ for O. oncorhynchi subsp. incaldanensis DSM $16557^{\mathrm{T}}$ ).

Strain CHL- $21^{\mathrm{T}}$ contained meso-diaminopimelic acid as diamino acid in the cell-wall peptidoglycan and MK-7 as the predominant menaquinone. The cellular fatty acid profile of strain CHL- $21^{\mathrm{T}}$ is shown in Table 2, together with those of related species of the genus Oceanobacillus. Strain CHL- $21^{\mathrm{T}}$ had large amounts of branched fatty acids; the major components ( $>10 \%$ of total fatty acids) were anteiso- $\mathrm{C}_{15: 0}$ and anteiso- $\mathrm{C}_{17: 0}$. The fatty acid profile of strain CHL- $21^{\mathrm{T}}$ was similar to those of other species of the genus Oceanobacillus in that anteiso- $\mathrm{C}_{15: 0}$ is the predominant fatty acid, although there were differences in the proportions of some fatty acids, particularly iso- $\mathrm{C}_{15: 0}$ and 
Table 1. Differential phenotypic characteristics of strain $\mathrm{CHL}-21^{\top}$ and the type strains of phylogenetically related species of the genus Oceanobacillus

Strains: 1 , Oceanobacillus locisalsi sp. nov. CHL-21 ${ }^{\mathrm{T}}$; 2, O. chironomi DSM $18262^{\mathrm{T}}$ (data from this study and Raats \& Halpern, 2007); 3, O. iheyensis DSM $14371^{\mathrm{T}}$ (data from this study and Lu et al., 2001); 4, O. oncorhynchi subsp. incaldanensis DSM $16557^{\mathrm{T}}$ (data from this study and Romano et al., 2006); 5, O. oncorhynchi subsp. oncorhynchi JCM $12661^{\mathrm{T}}$ (data from this study and Yumoto et al., 2005). All strains are positive for acid production from cellobiose, D-glucose, maltose, D-mannose and D-ribose, but negative for urease (data from this study). +, Positive; -, negative; W, weakly positive reaction.

\begin{tabular}{|c|c|c|c|c|c|}
\hline Characteristic & 1 & 2 & 3 & 4 & 5 \\
\hline Cell size $(\mu \mathrm{m})$ & $0.6-1.0 \times 1.3-4.0$ & $0.8-1.0 \times 1.3-3.0$ & $0.6-0.8 \times 2.5-3.5$ & $0.5-0.8 \times 1.2-2.0$ & $0.4-0.6 \times 1.1-1.4$ \\
\hline Colony colour & Cream-beige & Cream-beige & Cream-white & Beige & White \\
\hline Spore formation & + & + & + & - & + \\
\hline Anaerobic growth & + & - & - & - & + \\
\hline $\begin{array}{l}\text { Temperature range }\left({ }^{\circ} \mathrm{C}\right) \\
\text { (optimum) }\end{array}$ & $10-45(30-37)$ & $12-46(37)$ & $15-42(30)$ & $10-40(37)$ & $15-40(30-36)$ \\
\hline $\begin{array}{l}\mathrm{NaCl} \text { range (\%) for growth } \\
\text { (optimum) }\end{array}$ & $0-25(5-10)$ & $0-11(1-3)$ & $0-21(3)$ & $5-20(10)$ & $0-22(7)$ \\
\hline $\begin{array}{l}\mathrm{pH} \text { range for growth } \\
\text { (optimum) }\end{array}$ & $6.0-9.0(7.0-7.5)$ & $6.5-10.0(8.5)$ & $6.5-10.0(7.0-9.5)$ & $6.5-9.5(9.0)$ & $9-10$ \\
\hline Nitrate reduction* & + & + & - & + & + \\
\hline \multicolumn{6}{|l|}{ Hydrolysis of: ${ }^{*}$} \\
\hline Gelatin & - & + & + & - & + \\
\hline Aesculin & + & $\mathrm{w}$ & + & + & + \\
\hline Casein & - & + & + & + & + \\
\hline Tween 80 & + & + & + & $\mathrm{W}$ & + \\
\hline \multicolumn{6}{|l|}{ Acid production from:* } \\
\hline L-Arabinose & + & + & + & + & - \\
\hline D-Galactose & - & + & - & + & + \\
\hline D-Fructose & + & - & + & + & + \\
\hline Lactose & - & + & - & - & - \\
\hline Melibiose & - & + & - & + & + \\
\hline Melezitose & + & - & - & + & + \\
\hline Raffinose & - & $\mathrm{W}$ & - & + & + \\
\hline L-Rhamnose & - & - & $\mathrm{w}$ & - & - \\
\hline Trehalose & + & $\mathrm{w}$ & - & + & + \\
\hline Sucrose & + & - & - & + & + \\
\hline D-Xylose & + & + & + & + & - \\
\hline myo-Inositol & + & - & - & + & + \\
\hline D-Mannitol & + & - & + & + & + \\
\hline D-Sorbitol & + & - & - & - & + \\
\hline DNA G $+C$ content $(\mathrm{mol} \%)$ & 39.8 & 38.1 & 35.8 & 40.1 & 38.5 \\
\hline
\end{tabular}

${ }^{*}$ Data from this study.

anteiso- $\mathrm{C}_{17: 0}$ (Table 2). The DNA G $+\mathrm{C}$ content of strain CHL- $21^{\mathrm{T}}$ was $39.8 \mathrm{~mol} \%$.

Strain CHL- $21^{\mathrm{T}}$ was distinguishable from phylogenetically related species of the genus Oceanobacillus by differences in several phenotypic characteristics, as listed in Table 1 . The phylogenetic and genetic distinctiveness and differential phenotypic properties of strain $\mathrm{CHL}-21^{\mathrm{T}}$ are sufficient to categorize it as a member of a species that is distinct from recognized species of the genus Oceanobacillus (Wayne et al., 1987; Stackebrandt \& Goebel, 1994). Therefore, based on the data presented, strain CHL- $21^{\mathrm{T}}$ is considered to represent a novel species of the genus Oceanobacillus, for which the name Oceanobacillus locisalsi sp. nov. is proposed.

\section{Description of Oceanobacillus locisalsi sp. nov.}

Oceanobacillus locisalsi (lo.ci.sal'si. L. masc. n. locus place; L. adj. salsus salted, salt; N.L. gen. n. locisalsi of a salt place).

Cells are Gram-stain-variable rods $(0.6-1.0 \times 1.3-4.0 \mu \mathrm{m})$. Motile by means of a single polar flagellum. Central ellipsoidal endospores are observed in swollen sporangia. Colonies are circular, slightly convex, smooth, cream-beige in colour and $0.5-1.0 \mathrm{~mm}$ in diameter after incubation for 3 days at $30{ }^{\circ} \mathrm{C}$ on MSG agar. $\mathrm{Mg}^{2+}$ ions are required for growth. Growth under anaerobic conditions is observed on MSG agar and on MSG agar supplemented with nitrate. Catalase-positive and oxidase-negative. Tweens 20, 40 and 


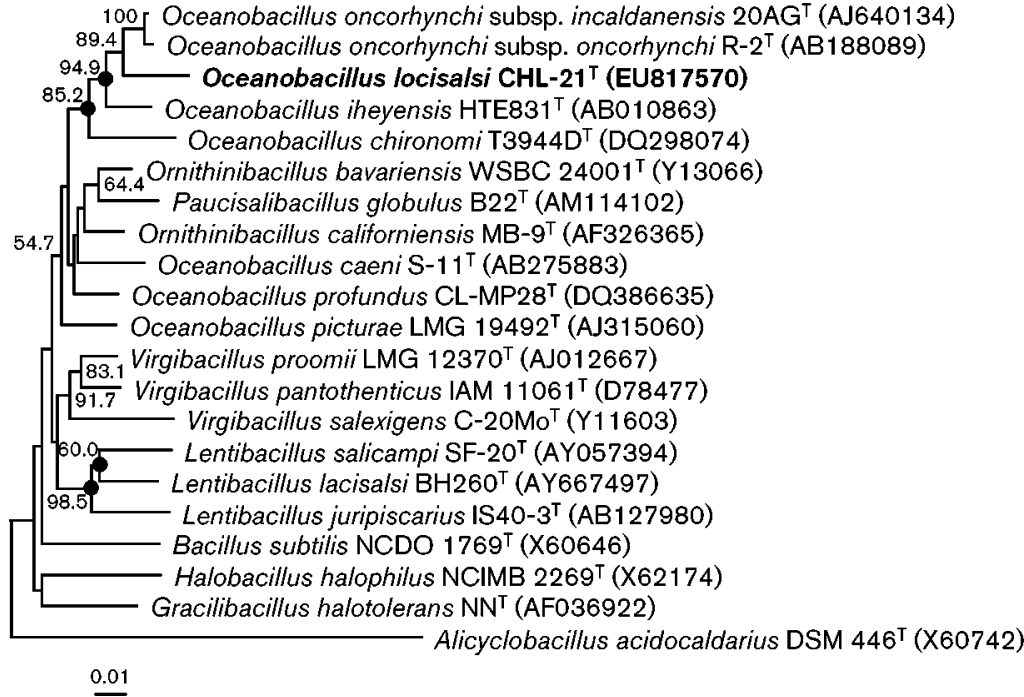

Fig. 1. Neighbour-joining phylogenetic tree based on 16S rRNA gene sequences showing the positions of strain $\mathrm{CHL}-21^{\top}$, other species of the genus Oceanobacillus and members of some other related taxa. Filled circles indicate nodes that were also recovered in trees generated with the maximum-likelihood and maximum-parsimony algorithms. Bootstrap values (expressed as percentages of 1000 replications) $>50 \%$ are shown at branch points. The outgroup was Alicyclobacillus acidocaldarius DSM $446^{\top}$ (GenBank accession no. X60742). Bar, 0.01 substitutions per nucleotide position.
60 are hydrolysed, but hypoxanthine, xanthine and starch are not. Indole is not produced. Susceptible to penicillin G, ampicillin, cephalothin, novobiocin, tetracycline, rifampicin, chloramphenicol, lincomycin, oleandomycin and carbenicillin, but not to polymyxin B, streptomycin, gentamicin, kanamycin, neomycin or erythromycin. In assays with the API ZYM system, leucine arylamidase, trypsin and $\alpha$ chymotrypsin are present, but alkaline phosphatase, esterase (C4), esterase lipase (C8), lipase (C14), valine arylamidase, cystine arylamidase, acid phosphatase, $\alpha$-galactosidase,

Table 2. Cellular fatty acid composition (\%) of strain CHL- $21^{\top}$ and the type strains of phylogenetically related species of the genus Oceanobacillus

Strains: 1, Oceanobacillus locisalsi sp. nov. CHL-21 ${ }^{\mathrm{T}} ; 2$, O. chironomi DSM $18262^{\mathrm{T}} ; 3$, O. iheyensis DSM $14371^{\mathrm{T}} ; 4$, O. oncorhynchi subsp. incaldanensis DSM $16557^{\mathrm{T}} ; 5$, O. oncorhynchi subsp. oncorhynchi JCM $12661^{\mathrm{T}}$. Data from this study. tr, Trace amount $(<0.5 \%) ;-$, not detected.

\begin{tabular}{|lccccc|}
\hline Fatty acid & $\mathbf{1}$ & $\mathbf{2}$ & $\mathbf{3}$ & $\mathbf{4}$ & $\mathbf{5}$ \\
\hline Straight-chain & & & & & \\
$\quad \mathrm{C}_{14: 0}$ & $\operatorname{tr}$ & $\operatorname{tr}$ & 0.6 & - & - \\
$\mathrm{C}_{15: 0}$ & - & 0.6 & $\operatorname{tr}$ & - & - \\
$\mathrm{C}_{16: 0}$ & 2.3 & 0.7 & 1.6 & 1.1 & 0.9 \\
$\mathrm{C}_{18: 0}$ & 1.2 & - & 0.6 & - & - \\
Unsaturated & & & & & \\
$\quad \mathrm{C}_{16: 1} \omega 7 c$ alcohol & - & - & 6.1 & $\operatorname{tr}$ & $\operatorname{tr}$ \\
Branched & & & & & \\
iso-C $\mathrm{C}_{14: 0}$ & 1.7 & 19.5 & 20.3 & 19.5 & 14.6 \\
iso-C $\mathrm{C}_{15: 0}$ & 7.3 & 1.5 & 32.5 & 11.8 & 8.3 \\
anteiso- $\mathrm{C}_{15: 0}$ & 46.2 & 47.4 & 20.3 & 26.3 & 36.8 \\
iso- $\mathrm{C}_{16: 0}$ & 6.7 & 20.3 & 12.1 & 27.4 & 25.8 \\
iso- $\mathrm{C}_{17: 0}$ & 4.0 & $\operatorname{tr}$ & 1.8 & 4.1 & 1.8 \\
anteiso- $\mathrm{C}_{17: 0}$ & 30.4 & 9.7 & 3.0 & 9.6 & 11.7 \\
& & & & & \\
\hline
\end{tabular}

$\beta$-glucuronidase, $\alpha$-glucosidase, $\beta$-galactosidase, $N$-acetyl- $\beta$ glucosaminidase, $\alpha$-mannosidase and $\alpha$-fucosidase are absent. The cell-wall peptidoglycan contains meso-diaminopimelic acid as the diamino acid. The predominant menaquinone is MK-7. The major fatty acids $(>10 \%$ of total fatty acids) are anteiso- $\mathrm{C}_{15: 0}$ and anteiso- $\mathrm{C}_{17: 0}$. Other phenotypic characteristics are given in Table 1.

The type strain is CHL- $21^{\mathrm{T}}\left(=\mathrm{KCTC} 13253^{\mathrm{T}}=\mathrm{CCUG}\right.$ $56608^{\mathrm{T}}$ ), isolated from a marine solar saltern of the Yellow Sea, Korea. The DNA G $+\mathrm{C}$ content of the type strain is $39.8 \mathrm{~mol} \%$.

\section{Acknowledgements}

This work was supported by the Program for Collection, Management and Utilization of Biological Resources (grant M10867010003) and the 21C Frontier Program of Microbial Genomics and Applications (grant MG05-0401-2-0) from the Ministry of Education, Science \& Technology (MEST) of the Republic of Korea and by a grant from the KRIBB Research Initiative Program.

\section{References}

Bruns, A., Rohde, M. \& Berthe-Corti, L. (2001). Muricauda ruestringensis gen. nov., sp. nov., a facultatively anaerobic, appendaged bacterium from German North Sea intertidal sediment. Int J Syst Evol Microbiol 51, 1997-2006.

Cowan, S. T. \& Steel, K. J. (1965). Manual for the Identification of Medical Bacteria. London: Cambridge University Press.

Ezaki, T., Hashimoto, Y. \& Yabuuchi, E. (1989). Fluorometric deoxyribonucleic acid-deoxyribonucleic acid hybridization in microdilution wells as an alternative to membrane filter hybridization in which radioisotopes are used to determine genetic relatedness among bacterial strains. Int J Syst Bacteriol 39, 224-229.

Heyrman, J., Logan, N. A., Busse, H.-J., Balcaen, A., Lebbe, L., Rodriguez-Diaz, M., Swings, J. \& De Vos, P. (2003). Virgibacillus carmonensis sp. nov., Virgibacillus necropolis sp. nov. and Virgibacillus picturae sp. nov., three novel species isolated from deteriorated mural 
paintings, transfer of the species of the genus Salibacillus to Virgibacillus, as Virgibacillus marismortui comb. nov. and Virgibacillus salexigens comb. nov., and emended description of the genus Virgibacillus. Int $J$ Syst Evol Microbiol 53, 501-511.

Kim, Y.-G., Choi, D. H., Hyun, S. \& Cho, B. C. (2007). Oceanobacillus profundus sp. nov., isolated from a deep-sea sediment core. Int J Syst Evol Microbiol 57, 409-413.

Komagata, K. \& Suzuki, K. (1987). Lipid and cell-wall analysis in bacterial systematics. Methods Microbiol 19, 161-207.

Lányí, B. (1987). Classical and rapid identification methods for medically important bacteria. Methods Microbiol 19, 1-67.

Lee, J.-S., Lim, J.-M., Lee, K. C., Lee, J. C., Park, Y.-H. \& Kim, C.-J. (2006). Virgibacillus koreensis sp. nov., a novel bacterium from a salt field, and transfer of Virgibacillus picturae to the genus Oceanobacillus as Oceanobacillus picturae comb. nov. with emended descriptions. Int J Syst Evol Microbiol 56, 251-257.

Leifson, E. (1963). Determination of carbohydrate metabolism of marine bacteria. J Bacteriol 85, 1183-1184.

Lu, J., Nogi, Y. \& Takami, H. (2001). Oceanobacillus iheyensis gen. nov., sp. nov., a deep-sea extremely halotolerant and alkaliphilic species isolated from a depth of $1050 \mathrm{~m}$ on the Iheya Ridge. FEMS Microbiol Lett 205, 291-297.

Nam, J.-H., Bae, W. \& Lee, D.-H. (2008). Oceanobacillus caeni sp. nov., isolated from a Bacillus-dominated wastewater treatment system in Korea. Int J Syst Evol Microbiol 58, 1109-1113.

Raats, D. \& Halpern, M. (2007). Oceanobacillus chironomi sp. nov., a halotolerant and facultatively alkaliphilic species isolated from a chironomid egg mass. Int J Syst Evol Microbiol 57, 255-259.

Romano, I., Lama, L., Nicolaus, B., Poli, A., Gambacorta, A. \& Giordano, A. (2006). Oceanobacillus oncorhynchi subsp. incaldanensis subsp. nov., an alkalitolerant halophile isolated from an algal mat collected from a sulfurous spring in Campania (Italy), and emended description of Oceanobacillus oncorhynchi. Int J Syst Evol Microbiol 56, 805-810.

Sasser, M. (1990). Identification of bacteria by gas chromatography of cellular fatty acids, MIDI Technical Note 101. Newark, DE: MIDI Inc.

Sehgal, S. N. \& Gibbons, N. E. (1960). Effect of some metal ions on the growth of Halobacterium cutirubrum. Can J Microbiol 6, 165-169.

Stackebrandt, E. \& Goebel, B. M. (1994). Taxonomic note: a place for DNA-DNA reassociation and $16 \mathrm{~S}$ rRNA sequence analysis in the present species definition in bacteriology. Int J Syst Bacteriol 44, 846-849.

Tamaoka, J. \& Komagata, K. (1984). Determination of DNA base composition by reversed-phase high-performance liquid chromatography. FEMS Microbiol Lett 25, 125-128.

Wayne, L. G., Brenner, D. J., Colwell, R. R., Grimont, P. A. D., Kandler, O., Krichevsky, M. I., Moore, L. H., Moore, W. E. C., Murray, R. G. E. \& other authors (1987). International Committee on Systematic Bacteriology. Report of the ad hoc committee on reconciliation of approaches to bacterial systematics. Int J Syst Bacteriol 37, 463-464.

Yoon, J.-H., Kim, H., Kim, S.-B., Kim, H.-J., Kim, W. Y., Lee, S. T., Goodfellow, M. \& Park, Y.-H. (1996). Identification of Saccharomonospora strains by the use of genomic DNA fragments and rRNA gene probes. Int J Syst Bacteriol 46, 502-505.

Yoon, J.-H., Lee, S. T. \& Park, Y.-H. (1998). Inter- and intraspecific phylogenetic analysis of the genus Nocardioides and related taxa based on 16S rDNA sequences. Int J Syst Bacteriol 48, 187-194.

Yoon, J.-H., Kim, I.-G., Shin, D.-Y., Kang, K. H. \& Park, Y.-H. (2003). Microbulbifer salipaludis sp. nov., a moderate halophile isolated from a Korean salt marsh. Int J Syst Evol Microbiol 53, 53-57.

Yumoto, I., Hirota, K., Nodasaka, Y. \& Nakajima, K. (2005). Oceanobacillus oncorhynchi sp. nov., a halotolerant obligate alkaliphile isolated from the skin of a rainbow trout (Oncorhynchus mykiss), and emended description of the genus Oceanobacillus. Int J Syst Evol Microbiol 55, 1521-1524. 